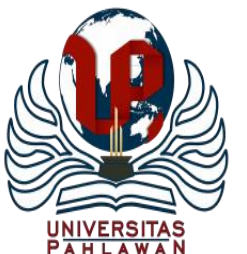

Jurnal Basicedu Volume 5 Nomor 1 Tahun 2021 Halaman 350-356

JURNAL BASICEDU

Research \& Learning in Elementary Education

https://jbasic.org/index.php/basicedu

\title{
Pengaruh Pembelajaran Berbasis Proyek Terhadap Keterampilan Berpikir Kreatif Ilmiah Sebagai Salah Satu Keterampilan Abad 21
}

\author{
Hilman Imadul Umam ${ }^{1}$, Salma Hikmatul Jiddiyyah ${ }^{2}$ \\ Universitas Muhammadiyah Tangerang 1,2 \\ Email : umam@umt.ac.id ${ }^{1}$, shjiddiyyah26@gmail.com²
}

\begin{abstract}
Abstrak
Penelitian ini dilakukan untuk mengetahui pengaruh pelaksanaan pembelajaran berbasis proyek terhadap keterampilan berpikir kreatif ilmiah siswa SMA dalam materi fluida dinamis. Keterampilan berpikir kreatif ilmiah merupakan salah satu keterampilan abad 21 yang sangat penting dimiliki oleh peserta didik supaya bisa beradaptasi terhadap perubahan. Desain penelitian yang digunakan adalah one-group pretestposttest design. Setelah dilaksanakan pembelajaran berbasis proyek pada sampel yang diteliti ternyata menunjukan adanya pengaruh terhadap peningkatan keterampilan berpikir kreatif ilmiah berdasarkan perhitungan effect size (d). Pelaksanaan pembelajaran berbasis proyek secara umum berpengaruh dalam meningkatkan keterampilan berpikir kreatif ilmiah berdasarkan nilai effect size (d) sebesar 1,32. Selanjutnya ditinjau berdasarkan aspek-aspek dari keterampilan berpikir kreatif ilmiah secara khusus, bahwa pembelajaran berbasis proyek berpengaruh dalam meningkatkan aspek thinking-fluency-technical product dan thinking-originality-technical product dengan nilai effect size (d) masing-masing sebesar 1,35 dan 1,21, tetapi tidak cukup efektif dalam meningkatkan aspek thinking-flexibility-technical product yang ditunjukan dari nilai effect size (d) yang hanya sebesar 0,14.
\end{abstract}

Kata Kunci: Pembelajaran berbasis proyek, keterampilan berpikir kreatif ilmiah, effect size.

\begin{abstract}
This research is conducted to determine the effectiveness of the implementation of project-based learning to improve the scientific creative thinking ability for high school students in dynamic fluid subject. The scientific creative thinking ability is one of the 21 st century skill that is very important owned by students in order to be able to adapt terhadap perubahan. Research design for this study is the one-group pretest-posttest design. The result of this research after the introduction of project-based learning showed an increase in scientific creative thinking ability based on calculation of effect size (d). The implementation of project-based learning is effective for improving scientific creative thinking ability with $d$ value 1,32 . The implementation of project-based learning is effective to improve the aspect of thinking-fluency-technical product and thinking-originality-technical product with $\mathrm{d}$ values respectively 1,35 and 1,21 , but it is not effective to improve the aspect of the thinking-flexibility-technical product with d value 0,14 .
\end{abstract}

Keywords: Project-based learning, The scientific creative thinking ability, effect size.

Copyright (c) 2021 Hilman Imadul Umam, Salma Hikmatul Jiddiyyah

$\triangle$ Corresponding author :

Address : Jl. Perintis kemerdekaan 1 Babakan, Cikokol, Kota Tangerang ISSN 2580-3735 (Media Cetak)

Email : umam@umt.ac.id

Phone : 081310941700

ISSN 2580-1147 (Media Online)

DOI: https://doi.org/10.31004/basicedu.v5i1.645 
351 Pengaruh Pembelajaran Berbasis Proyek Terhadap Keterampilan Berpikir Kreatif Ilmiah Sebagai Salah Satu Keterampilan Abad 21 - Hilman Imadul Umam, Salma Hikmatul Jiddiyah

DOI: https://doi.org/10.31004/basicedu.v5i1.645

\section{PENDAHULUAN}

Keterampilan abad 21 atau $21^{\text {st }}$ Century Skills merupakan keterampilan yang sangat penting dimiliki oleh peserta didik khususnya di tingkat sekolah menengah atas supaya dapat beradaptasi dengan dunia yang semakin maju dan berkembang khususnya dalam bidang media informasi dan teknologi. Salah satu keterampilan abad 21 adalah keterampilan belajar dan berinovasi yang meliputi berpikir kritis dan mengatasi masalah (critical thinking and problem solving), komunikasi dan kolaborasi (communication and collaboration), serta kreativitas dan inovasi (creativity and innovation). Aspek dari keterampilan belajar dan berinovasi tersebut dikenal juga dengan sebutan $4 \mathrm{C}$ yaitu critical thinking, creativity, communication, collaboration (Trilling \& Fadel, 2009).

Proses pendidikan dan pembelajaran menjadi sangat penting dalam menjamin peserta didik memiliki keterampilan abad 21 terutama keterampilan belajar dan berinovasi (Kuntari Eri \& Widyaiswara, 2013). Sehingga diperlukan pembelajaran yang bisa meningkatkan aspek-aspek dari keterampilan belajar dan berinovasi yang menuntut siswa mampu memanfaatkan pengetahuan yang didapat menjadi ide yang bisa digunakan sebagai solusi dari suatu persoalan. Salah satu aspek dalam keterampilan belajar dan berinovasi yang melatihkan siswa menghasilkan ide untuk menyelesaikan suatu persoalan adalah aspek kreativitas.

Kreativitas terjadi melalui serangkaian tahap-tahap kecil dari sebuah ide awal yang mampu dimodifikasi dan diuraikan secara jelas (Weisberg, 2006). Seseorang bisa menjadi kreatif dalam bidang yang spesifik, contohnya ada orang yang kreatif dalam bidang sains tetapi tidak dalam menggambar (Liang, 2002). Sehingga dalam konteks proses pembelajaran, kreatifitas yang dimaksud adalah kreatifitas ilmiah yang berkaitan dengan merancang percobaan baru untuk menyelidiki hukum-hukum alam, mengembangkan ide ilmiah yang diterapkan pada ranah praktis, implementasi rencana untuk aktifitas ilmiah, dan banyak lagi (Moravcsik, 1981).

Pembelajaran berbasis proyek (PBP) memberikan ruang kebebasan bagi siswa untuk menentukan pembelajarannya sendiri secara kolaboratif dan menuntut siswa untuk dapat memberikan berbagai ide dalam membuat proyek berdasarkan pengetahuan yang siswa tersebut miliki (Bell, 2010). Penerapan PBP juga membuat siswa mampu memecahkan masalah secara kolaboratif dan memiliki keterampilan untuk dapat memanfaatkan pengetahuannya dalam pengambilan keputusan (Colley, 2008). Melalui tantangan dan aktivitas yang menarik dalam pembuatan proyek, siswa dapat mengembangkan kemampuan untuk mengoperasikan dan memahami konsep dari suatu pengetahuan yang disampaikan oleh guru (Yalçin et al., 2009). Sehingga PBP bisa menjadi salah satu alternatif model pembelajaran yang dapat mendukung peningkatan keterampilan berpikir kreatif, berpikir kritis, berkomunikasi, dan berkolaborasi (Mayasari et al., 2016).

Berdasarkan latar belakang tersebut maka pada penelitian ini dilakukan pengukuran pengaruh dari pembelajaran berbasis proyek terhadap peningkatakan keterampilan berpikir kreatif ilmiah siswa SMA. Besarnya pengaruh pembelajaran berbasis proyek tersebut dilihat dari efektivitasnya berdasarkan nilai dari effect size (d). Sehingga melalui penelitian ini bisa diketahui secara kuantitatif seberapa besar efektivitas penerapan pembelajaran berbasis proyek terhadap peningkatan keterampilan berpikir kreatif ilmiah siswa SMA. 
352 Pengaruh Pembelajaran Berbasis Proyek Terhadap Keterampilan Berpikir Kreatif Ilmiah Sebagai Salah Satu Keterampilan Abad 21 - Hilman Imadul Umam, Salma Hikmatul Jiddiyah

DOI: https://doi.org/10.31004/basicedu.v5i1.645

\section{METODE}

Metode penelitian yang digunakan adalah metode pre-experimental dengan desain penelitian one-group pretest-posttest design (Sugiyono, 2014). Dalam desain penelitian tersebut kelompok eksperimen diberikan tes awal (pretest) sebelum melaksanakan pembelajaran dan diberikan tes akhir (posttest) setelah diberikan perlakuan (treatment) berupa pembelajaran berbasis proyek. Adapun skema desain penelitian one-group pretest-posttest design dapat dilihat pada Tabel 1 berikut:

Tabel 1. Skema One-Group Pretest-Posttest Design

\begin{tabular}{|c|c|c|c|}
\hline Kelas & Pretest & Treatment & Posttest \\
\hline Eksperimen & $\mathrm{O}_{1}$ & $\mathrm{x}$ & $\mathrm{O}_{2}$ \\
\hline
\end{tabular}

Keterangan :

$\mathrm{O}_{1}=$ Tes awal (pretest)

$\mathrm{O}_{2}=$ Tes akhir (posttest)

$\mathrm{x}=$ Perlakuan (Treatment)

Populasi pada penelitian ini adalah siswa kelas XI IPA SMA di salah satu SMA yang berada di kota Bandung. Sampel diambil dari salah satu kelas XI IPA tersebut dengan teknik purposive sampling. Dua jenis instrumen digunakan dalam penelitian ini antara lain lembar observasi untuk mengukur keterlaksanaan pembelajaran berbasis proyek dan instrumen tes keterampilan berpikir kreatif ilmiah dalam bentuk uraian yang penyusunannya berdasarkan perpaduan aspek keterampilan berpikir kreatif ilmiah menurut Scientific Structure Creativity Models ( $\mathrm{Hu} \&$ Adey, 2002). Perpaduan aspek tersebut meliputi aspek process (thinking \& imagination), aspek trait (fluency, flexibility, \& originality), dan aspek product (technical product, science knowledge, science phenomena, \& science problem).

Pemberian skor pada tes keterampilan berpikir kreatif ilmiah mengacu pada jawaban yang diberikan oleh siswa pada setiap aspek keterampilan berpikir ilmiah yang diteskan $(\mathrm{Hu} \&$ Adey, 2002). Skor untuk aspek thinking-fluencytechnical product ditentukan berdasarkan jumlah jawaban yang diberikan siswa, skor untuk aspek thinking-felxibility-technical product ditentukan berdasarkan jumlah sudut pandang dari jawaban yang diberikan siswa, dan skor untuk aspek thinking-originality-technical product ditentukan melalui frekuensi dan persentase dari setiap jawaban siswa yang telah diklasifikasikan berdasarkan kebaruan dari konten jawaban yang diberikan.

Besarnya efektivitas penerapan pembelajaran berbasis proyek dalam meningkatkan keterampilan berpikir kreatif ilmiah secara kuantitatif bisa ditentunkan dari nilai effect size (d). Menurut Dunts, C, J., (2004), effect size digunakan untuk mengukur seberapa efektif hubungan antara variable bebas dengan variable terikat. Pada penelitian ini karena hanya menggunakan satu kelompok sampel sebagai kelas eksperimen maka digunakan effect size untuk nonindependent group of study participants (Dunst et al., 2004). Berikut merupakan rumus dari Cohen's $d$ effect size yang digunakan pada penelitian ini:

$$
d=\frac{M_{2}-M_{1}}{S_{\text {pooled }}}
$$

Keterangan:

$\mathrm{d}=$ Cohen's d effect size

$M_{1} \quad$ = rata-rata skor pretest

$M_{2} \quad$ = rata-rata skor posttest

$S_{\text {pooled }}=$ standar deviasi gabungan

Standar deviasi gabungan bisa didapatkan dari persamaan berikut:

$$
S_{\text {pooled }}=\sqrt{\frac{S D_{1}{ }^{2}+S D_{2}{ }^{2}}{2}}
$$


353 Pengaruh Pembelajaran Berbasis Proyek Terhadap Keterampilan Berpikir Kreatif Ilmiah Sebagai Salah Satu Keterampilan Abad 21 - Hilman Imadul Umam, Salma Hikmatul Jiddiyah

DOI: https://doi.org/10.31004/basicedu.v5i1.645

$S D_{1}^{2}=$ varians skor pretest

$S D_{2}^{2}=$ varians skor posttest

Interpretasi nilai Cohen's $d$ ditunjukan pada

Tabel 2 (Becker, 1999) di bawah ini:

Tabel 2. Kriteria interpretasi nilai Cohen's d effect size

\begin{tabular}{|c|c|}
\hline Cohen's d effect size & Kriteria \\
\hline$d \geq 2,1$ & Sangat tinggi \\
\hline $0,8 \leq d \leq 2,0$ & Tinggi \\
\hline $0,5 \leq d \leq 0,79$ & Sedang \\
\hline $0,2 \leq d \leq 0,49$ & Rendah \\
\hline $0,0 \leq d \leq 0,19$ & Sangat rendah \\
\hline
\end{tabular}

\section{HASIL DAN PEMBAHASAN}

Keterlaksanaan proses pembelajaran berbasis proyek diukur berdasarkan lembar observasi yang memuat kegiatan-kegiatan yang harus dilaksanakan guru maupun siswa selama proses pembelajaran berlangsung. Berdasarkan hasil observasi yang dilakukan selama pemberian treatment penerapan pembelajaran berbasis proyek pada kelas eksperimen didapatkan persentase keterlaksanaan seperti pada Tabel 3 berikut ini:

Tabel 3. Keterlaksanaan kegiatan PBP

\begin{tabular}{|c|c|c|}
\hline \multirow{2}{*}{ Pertemuan } & \multicolumn{2}{|c|}{ Persentase keterlaksanaan (\%) } \\
\cline { 2 - 3 } & Kegiatan guru & Kegiatan siswa \\
\hline 1 & 97,8 & 97,8 \\
\hline 2 & 100 & 100 \\
\hline Rata-rata & 98,9 & 98,9 \\
\hline
\end{tabular}

Persentase rata-rata keterlaksanaan kegiatan guru maupun siswa sebesar 98,9\% yang termasuk kedalam kriteria sangat tinggi atau hampir seluruh kegiatan guru dan siswa dalam proses pembelajaran berbasis proyek terlaksana. Meskipun dalam pelaksanaannya belum berjalan dengan sempurna karena berbagai hal seperti keterbatasan waktu kegiatan belajar dan mengajar yang terbatas.
Keterbatasan waktu tersebut disebabkan juga karena dalam pembelajaran berbasis proyek membutuhkan waktu yang lebih banyak dibandingkan kegiatan pembelajaran lainnya, zperti diungkapkan oleh Heckendorn (2002) ahwa pembelajaran berbasis proyek Iembutuhkan waktu yang jauh lebih banyak ibandingkan dengan pembelajaran lainnya karena egiatan pembelajaran dikondisikan seolah siswa ıenghadapi permasalahan dalam kehidupan nyata (Heckendorn, 2002).

Kekurangan kegiatan pembelajaran di pertemuan 1 adalah tidak terlaksananya kegiatan guru memeriksa kehadiran siswa di awal pembelajaran sehingga tidak adanya kegiatan siswa dalam merespon pemeriksaan kehadiran.

Selanjutnya, berdasarkan hasil pretest dan posttest dengan menggunakan instrumen tes untuk mengukur keterampilan berpikir kreatif ilmiah yang kemudian diolah dengan menggunakan rumus Cohen's $d$ effect size didapatkan nilai ratarata skor pretest dan posttest, standar deviasi, dan nilai effect size $(d)$ seperti pada Tabel 4 berikut:

Tabel 4. Nilai pretest-posttest, standar deviasi, dan effect size $(d)$

\begin{tabular}{|c|c|c|c|c|c|}
\hline \multicolumn{2}{|c|}{ Rata-rata } & \multicolumn{2}{|c|}{ Standar deviasi } & \multirow{2}{*}{ S } & \multirow{2}{*}{$\boldsymbol{d}$} \\
\cline { 1 - 4 } Pretest & Posttest & Pretest & Posttest & & \\
\hline 10,22 & 15,72 & 3,02 & 4,90 & 4,12 & 1,32 \\
\hline
\end{tabular}

Didapatkan bahwa rata-rata hasil pretest dan posttest berturut-turut sebesar 10,22 dan 15,72 yang memiliki selisih sebesar 5,50 . Hal tersebut menunjukan adanya peningkatan keterampilan berpikir kreatif ilmiah setelah diterapkannya pembelajaran berbasis proyek. Kemudian analisis data untuk melihat seberapa efektif penerapan pembelajaran berbasis proyek dalam meningkatkan keterampilan berpikir ilmiah didapatkan berdasarkan nilai effect size $(d)$ sebesar 1,32 dan termasuk dalam kategori tinggi. Sehingga 
354 Pengaruh Pembelajaran Berbasis Proyek Terhadap Keterampilan Berpikir Kreatif Ilmiah Sebagai Salah Satu Keterampilan Abad 21 - Hilman Imadul Umam, Salma Hikmatul Jiddiyah

DOI: https://doi.org/10.31004/basicedu.v5i1.645

berdasarkan nilai effect size (d) tersebut dapat dikatakan bahwa penerapan pembelajaran berbasis proyek sangat efektif dalam meningkatkan keterampilan berpikir kreatif ilmiah. Hasil pengolahan data dan analisis dari nilai effect size (d) sejalan dengan pernyataan Bell (2010) yang menyakatan bahwa pembelajaran berbasis proyek membuat siswa dapat mengembangkan keterampilan kreatif dalam proses perencanaan dan pembuatan proyek.

Pengolahan data dan analisis berlanjut untuk aspek-aspek keterampilan berpikir ilmiah yaitu thinking-fluency-technical product, thinkingflexibility-technical product, dan thinkingoriginality-techinical products, sehingga didapatkan nilai rata-rata skor pretest dan posttest, standar deviasi, dan effect size (d) disajikan pada Tabel 5 berikut:

Tabel 5. Nilai pretest-posttest, standar deviasi, dan effect size (d) untuk setiap aspek

\begin{tabular}{|c|c|c|c|c|}
\hline \multicolumn{2}{|c|}{$\begin{array}{c}\text { Aspek keterampilan } \\
\text { berpikir kreatif } \\
\text { ilmiah }\end{array}$} & Fluency & Flexibility & Originality \\
\hline \multirow{2}{*}{$\begin{array}{c}\text { Rata- } \\
\text { rata }\end{array}$} & Pretest & 7,13 & 2,78 & 0,31 \\
\cline { 2 - 5 } & Posttest & 11,20 & 3,02 & 1,46 \\
\hline \multirow{2}{*}{$\begin{array}{c}\text { Standar } \\
\text { deviasi }\end{array}$} & Pretest & 2,46 & 1,33 & 0,65 \\
\cline { 2 - 5 } & Posttest & 3,44 & 1,71 & 1,15 \\
\hline \multicolumn{2}{|c|}{$S_{\text {pooled }}$} & 9,01 & 2,33 & 0,87 \\
\hline \multicolumn{2}{|c|}{$d$} & 1,35 & 0,14 & 1,21 \\
\hline
\end{tabular}

Berdasarkan Tabel 5, nilai pretest dan posttest untuk aspek thinking-fluency-technical product berturut-turut sebesar 7,13 dan 11,20 sehingga diperoleh selisis sebesar 4,07 yang menunjukan adanya peningkatan aspek tersebut setelah diterapkannya pembelajaran berbasis proyek. Selanjutnya berdasarkan perhitungan effect size didapatkan nilai sebesar 1,35 yang termasuk dalam kategori tinggi yang menunjukan bahwa penerapan pembelajaran berbasis proyek sangat efektif dalam meningkatkan aspek thinkingfluency-technical product. Hal tersebut menunjukan bahwa proses pembelajaran berbasis proyek yang menuntut siswa supaya bisa memanfaatkan pengetahuan yang dimilikinya untuk menghasilkan ide-ide dalam menyelesaikan persoalan memberi dampak terhadap peningkatan kemampuan fluency yang diartikan sebagai kemampuan untuk menghasilkan ide-ide baru $(\mathrm{Hu}$ \& Adey, 2002).

Aspek berikutnya yaitu thinking-originalitytechnical product menunjukan nilai rata-rata pretest dan posttest berturut-turut sebesar 2,78 dan 3,02 sehingga selisisnya sebesar 0,24 . Nilai selisis rsebut bisa dikatakan tidak terlalu besar sehingga ningkatan keterampilan dalam aspek thinkingiginality-technical product tidak terlalu gnifikan. Kemudian berdasarkan perhitungan fect size (d) didapatkan nilai sebesar 0,14 yang rmasuk dalam kategori rendah. Artinya bahwa nerapan pembelajaran berbasis proyek tidak ıkup efektif dalam meningkatkan aspek :terampilan thinking-originality-technical oduct. Aspek ini berkaitan dengan kemampuan Ituk mengubah cara dalam menyelesaikan rsoalan dan tidak terpaku pada pendekatan awal yang kurang efisien. Nilai effect size (d) yang rendah untuk aspek ini disebabkan karena siswa terlalu mengacu pada pengetahuan yang didapat saat proses pembelajaran sehingga membuat pemikirannya menjadi kaku yang akhirnya kurang bisa mencari cara lain dalam menyelesaikan persoalan.

Aspek terakhir yang dianalisis dari keterampilan berpikir kreatif ilmiah adalah 
355 Pengaruh Pembelajaran Berbasis Proyek Terhadap Keterampilan Berpikir Kreatif Ilmiah Sebagai Salah Satu Keterampilan Abad 21 - Hilman Imadul Umam, Salma Hikmatul Jiddiyah

DOI: https://doi.org/10.31004/basicedu.v5i1.645

thinking-originality-techinical

products.

Berdasarkan hasil pretest dan posttest didapatkan berturut-turut nilai sebesar 0,31 dan 1,46 sehingga selisihnya adalah 1,15 . Sedangkan berdasarkan perhitungan effect size (d) didapatkan nilai sebesar 1,21 yang termasuk kedalam kategori tinggi. Artinya bahwa penerapan pembelajaran berbasis proyek sangat efektif dalam meningkatkan keterampilan untuk aspek thinking-originalitytechinical products. Aspek originality ini berkaitan dengan bagaimana seorang siswa mampu menghasilkan ide unik dan orisinil yang sebelumnya belum ada. Penyelesaian masalah yang dilakukan secara individu membuat siswa dapat memberikan ide atau gagasan tanpa dipengaruhi oleh ide atau gagasan siapapun sehingga menghasilkan solusi yang unik dan orisinil. Kemampuan tersebut dapat ditingkatkan dalam tahapan perencanaan dan pembuatan proyek yang pada tahapan tersebut siswa dituntut untuk mengembangkan rencana terkait proyek yang akan dibuat. Setelah itu siswa harus mampu mengembangkan pengetahuan yang dimilikinya untuk menyelesaikan persoalan dalam pembuatan proyek (Hugerat, 2016). Sehingga melalui tahapan tersebut kemampuan siswa dalam aspek thinkingoriginality-techinical products secara langsung akan terlatih dan terjadi peningkatan.

\section{SIMPULAN}

Pembelajaran berbasis proyek untuk meningkatkan keterampilan berpikir kreatif ilmiah telah diterapkan dalam penelitian ini dengan persentase keterlaksanaan sebesar $98,9 \%$ atau hampir seluruh kegiatan pembelajaran dilaksanakan baik oleh guru maupun siswa. Kemudian berdasarkan hasil analisis perhitungan effect size (d) didapatkan bahwa penerapan pembelajaran berbasis proyek secara umum efektif dalam meningkatkan keterampilan berpikir kreatif ilmiah dengan nilai effect size (d) sebesar 1,32 yang termasuk dalam kategori tinggi. Sedangkan untuk tinjauan setiap aspek dari keterampilan berpikir kreatif ilmiah didapatkankan bahwa pembelajaran berbasis proyek efektif untuk meningkatkan aspek thinking-fluency-technical product dan thinking-originality-techinical products dengan nilai effect size $(d)$ beruturu-turut sebesar 1,35 dan 1,21 yang termasuk dalam kategori tinggi. Aspek lainnya yaitu thinkingflexibility-technical product mendapatkan nilai effect size (d) sebesar 0,14 atau masuk ke dalam kategori sangat rendah yang menunjukan bahwa penerapan pembelajaran berbasis proyek tidak cukup efektif dalam meningkatkan aspek keterampilan tersebut.

\section{DAFTAR PUSTAKA}

Becker, L. a. (1999). University of Colorado Colorado Springs, UCCS. Effect Size Calculators.

Bell, S. (2010). Project-Based Learning for the 21st Century: Skills for the Future. The Clearing House: A Journal of Educational Strategies, Issues and Ideas. https://doi.org/10.1080/00098650903505415

Colley, K. (2008). Project-based science instruction: A primer. The Science Teacher.

Dunst, C. J., Hamby, D. W., \& Trivette, C. M. (2004). Guidelines for Calculating Effect Sizes for Practice-Based Research Syntheses. Centerscope.

Heckendorn, R. B. (2002). Building a beowulf: Leveraging research and department needs for student enrichment via project based learning. Computer Science Education. https://doi.org/10.1076/csed.12.4.255.8620

Hu, W., \& Adey, P. (2002). A scientific creativity test for secondary school students. International Journal of Science Education. https://doi.org/10.1080/09500690110098912

Hugerat, M. (2016). How teaching science using project-based learning strategies affects the classroom learning environment. Learning 
356 Pengaruh Pembelajaran Berbasis Proyek Terhadap Keterampilan Berpikir Kreatif Ilmiah Sebagai Salah Satu Keterampilan Abad 21 - Hilman Imadul Umam, Salma Hikmatul Jiddiyah

DOI: https://doi.org/10.31004/basicedu.v5i1.645
Environments
Research.
https://doi.org/10.1007/s10984-016-9212-y

Kuntari Eri, M., \& Widyaiswara, M. (2013). Pendidikan Abad 21 Dan Implementasinya Pada Pembelajaran Di Sekolah Menengah Kejuruan (SMK) Untuk Paket Keahlian Desain Interior. Artikel Kurikulum 2013 SMK.

Liang, J.-C. (2002). Exploring Scientific Creativity of Eleventh Grade Students in Taiwan. In Faculty of the Graduate School .

Mayasari, T., Kadarohman, A., Rusdiana, D., \& Kaniawati, I. (2016). APAKAH MODEL PEMBELAJARAN PROBLEM BASED LEARNING DAN PROJECT BASED LEARNING MAMPU MELATIHKAN KETERAMPILAN ABAD 21? Jurnal Pendidikan Fisika Dan Keilmuan (JPFK). https://doi.org/10.25273/jpfk.v2i1.24

Moravcsik, M. J. (1981). Creativity in science education. Science Education. https://doi.org/10.1002/sce.3730650212

Sugiyono. (2014). Metode Penelitian Pendidikan pendekatan Kuantitatif, Kualitatif dan R\&D. In METODE PENELITIAN ILMIAH.

Trilling, B., \& Fadel, C. (2009). What is 21st Century Learning? 21st Century Skills: Learning for Life in Our Times.

Weisberg, R. W. R. W. (2006). Creativity: Understanding innovation in problem solving, science, invention, and the arts. Creativity.

Yalçin, S. A., Turgut, Ü., \& Büyükkasap, E. (2009). The effect of project based learning on science undergraduates' learning of electricity, attitude towards physics and scientific process skills. International Online Journal of Educational Sciences. 